\title{
Use of Neem leaves as soil amendment for the control of collar rot disease of chickpea
}

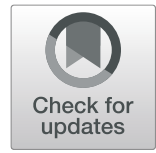

Iqra Haider Khan ${ }^{1}$, Arshad Javaid ${ }^{1 *} \mathbb{D}$, Azher Hameed Al-Taie ${ }^{2}$ and Dildar Ahmed ${ }^{3}$

\begin{abstract}
Chickpea (Cicer arietinum L.) is an important grain legume that is attacked by the fungal pathogen, Sclerotium rolfsii, responsible for collar rot disease. In the present study, the pathogen was isolated from diseased chickpea seedlings and identified on molecular basis using internal transcribed spacer (ITS) and $\beta$-tubulin markers. To control this pathogen, an in vivo study was carried out, using Neem (Azadirachta indica A. Juss.) leaf dry biomass (1, 2, and 3\%) as soil amendment. A broad-spectrum fungicide mancozeb was selected as a reference and the data regarding plant growth and mortality rates were calculated. In positive control, the highest seedling mortality (56\%) was recorded in comparison to negative control (0\%) after 30 days of sowing. In 1, 2, and $3 \%$ concentrations of $A$. indica dry leaf biomass, the seedling mortalities were 49,38, and 38\%, respectively. On the other hand, the mancozebtreated seedlings showed the lowest plant mortality rate (28\%). Soil treatments with mancozeb as well as with 1 and $2 \%$ leaf biomass concentrations showed marked differences in root and shoot dry biomasses over positive control. In a laboratory bioassay, methanolic leaf extract of Neem of 0.5 to $3.5 \%$ concentrations reduced biomass of S. rolfsii by $86-90 \%$ over control. The present study concluded that $2 \%$ A. indica leaf amendment was the most useful concentration for management of collar rot disease of chickpea.
\end{abstract}

Keywords: Azadirachta indica, Chickpea, Collar rot, Natural fungicide, Soil amendment

\section{Background}

Chickpea (Cicer arietinum L.) is an important grain legume providing an enormous source of minerals, fibers, and proteins both for humans and animals (Varol et al. 2020). It is considered as the drought resistant winter season annual crop grown widely in Pakistani and Indian subcontinent regions (Ilyas et al. 2007). In Pakistan, the total area under chickpea cultivation is 978,000 ha with an annual production of 340,000 t (Pakistan Economic Survey 2017-18). Also, the production of chickpea is very low due to many factors like pathogenic attacks and environmental stresses such as heat, cold, and salinity. A number of pathogens have been reported to attack the crop. Among these, a soil-borne fungal pathogen Sclerotium rolfsii is responsible for collar rot disease of chickpea. It was reported that the pathogen attacks the

\footnotetext{
*Correspondence: arshad.iags@pu.edu.pk; arshadjpk@yahoo.com ${ }^{1}$ Institute of Agricultural Sciences, University of the Punjab, Lahore, Pakistan Full list of author information is available at the end of the article
}

crop at seedling stage causing severe yield losses in tropical and sub-tropical areas of the world (Javaid and Khan 2016 and Tarafdar et al. 2018). Seedling mortality due to this disease ranges from 55 to $95 \%$ (Kokub et al. 2007). The pathogen was reported from Asia, South East Asia, Indian subcontinent, Australia, and America (Maurya et al. 2007). It can cause diseases in 500 host plant species belonging to 100 families (Remesal et al. 2013). It forms appreciable number of sclerotia, which can remain in soil for several years (Farr et al. 2007).

For the control of collar rot disease, generally chemical control is considered the most practical strategy (Javaid and Khan 2016). However, synthetic agrochemicals besides controlling pathogens also have toxic effects in soil, water, and food products; thus, their substantial use should be discouraged (Bundschuh et al. 2016). These are also detrimental to many non-target organisms. In addition, use of fungicides also leads to the emergence of many new fungicide resistant strains, resulting in disturbance in ecological balance (Weber et al. 2018). 
There is a need to replace synthetic agrochemicals with alternative environment friendly methods. In the recent years, many successful attempts have been made in this regard and scientists have reported that use of plant dry biomasses of Chenopodium album, C. murale, Coronopus didymus, Eucalyptus citriodora, Eruca sativa, and Sisymbrium irio as soil amendment can effectively control soil-borne pathogens namely, Fusarium oxysporum, Sclerotium rolfsii, Rhizoctonia solani, and Macrophomina phaseolina (Javaid et al. 2017a,b; Bajwa et al. 2019; Hadi et al. 2019; Naqvi et al. 2019 and Javaid et al. 2020).

The present study aimed to control collar rot disease of chickpea by practicing Neem leaf dry biomass as soil amendment.

\section{Materials and methods}

\section{Molecular characterization of S. rolfsii}

$S$. rolfsii was isolated from diseased seedlings of chickpea. Molecular characterization was done to confirm its identity with internal transcribed spacer (ITS) and beta tubulin markers through PCR amplification (Table 1). Pure culture of S. rolfsii was scratched from 2-week-old malt extract agar (MEA) plates and DNA was isolated by CTAB method (Doyle and Doyle 1990), using the fungal DNA extraction kit of GeneAll Biotechnology Co., Ltd. PCR was performed in a 30- $\mu$ l reaction system with ITS and beta tubulin primer pairs for rDNA amplification. Amplified PCR products were got sequenced from 1st Base Sequencing Singapore Co., Ltd.

\section{In vitro antifungal activity of methanolic leaf extract}

For preparation of extract and antifungal bioassays, protocol given by Ali et al. (2017a) was adopted with little modifications. A. indica leaves were collected from Lahore, Pakistan, dried and crushed. Finely crushed material $(200 \mathrm{~g})$ was used for extraction in $1.0 \mathrm{l}$ of methanol for 10 days and filtered subsequently through a Whatman No. 1 filter paper. Next, the filtrate was undergone to a rotary evaporator at $45^{\circ} \mathrm{C}$ to get $20 \mathrm{~g}$ of thick gummy material.

For the preparation of stock solution, $11.2 \mathrm{~g}$ of crude methanolic extract was dissolved in $6 \mathrm{ml}$ of dimethyl sulfoxide (DMSO) and raised the volume up to $14 \mathrm{ml}$ by adding distilled water. A control solution was prepared simultaneously with the same amount of DMSO and water, but without the addition of plant extract. Seven concentrations viz. 3.5, 3.0, 2.5, 2.0, 1.5, 1.0, 0.5, $0 \mathrm{~g}$ $100 \mathrm{ml}^{-1}$ were formulated by the addition of 3.5, 3.0, $2.5,2.0,1.5,1.0,0.5$, and $0 \mathrm{ml}$ of stock solution and $0,0.5,1.0,1.5,2.0,2.5,3.0$, and $3.5 \mathrm{ml}$ control solution, respectively, to different flasks having $76.5 \mathrm{ml}$ of malt extract broth then mixed well and poured into 4 equal aliquots in $100 \mathrm{ml}$ flasks, each was run simultaneously as a replicate. Mycelial plugs $(5 \mathrm{~mm})$ of 7day-old $S$. rolfsii culture were added in each conical flask and left to stand for 7 days at $25 \pm 2{ }^{\circ} \mathrm{C}$. Thereafter, the fungal biomass was filtered and dried in an electric oven at $60^{\circ} \mathrm{C}$ (Javaid et al. 2017c).

\section{Pot trial}

S. rolfsii inoculum was prepared on $1.0 \mathrm{~kg}$ boiled and autoclaved seeds of pearl millet in three $500 \mathrm{ml}$ of conical flasks and kept for 15 days in an incubator at $25 \pm$ $2{ }^{\circ} \mathrm{C}$ until profuse sporulation occurred. Freshly prepared $15 \mathrm{~g}$ of fungal inoculum was then mixed in $1 \mathrm{~kg}$ of fumigated sandy loam soil in 10-cm deep and 15-cm diameter plastic pots, except in negative treatment which was supplied only by $15 \mathrm{~g}$ of boiled pearl millet and left for 10 days. After that, the soils of the respective pots were amended with $A$. indica dry leaf powder at different concentrations viz. 1,2 , and $3 \%(\mathrm{w} / \mathrm{w})$ and irrigated. The pots were left for 1 week for leaching of soil (Javaid and Saddique 2011). Mancozeb fungicide concentration of $150 \mathrm{ppm}$ was prepared and applied $\left(0.51 \mathrm{pot}^{-1}\right)$ to pots of respective treatment.

The following 6 treatments, with 5 replicates each were arranged in a completely randomized design:

$\mathrm{T}_{1}$ Negative control (without $S$. rolfsii or dry leaf biomass)

$\mathrm{T}_{2}$ Positive control [inoculated with $S$. rolfsii (SR)]

$\mathrm{T}_{3} \mathrm{SR}+$ mancozeb

$\mathrm{T}_{4} \mathrm{SR}+1 \%$ dry leaf biomass (DLB) of $A$. indica

$\mathrm{T}_{5} \mathrm{SR}+2 \% \mathrm{DLB}$ of $A$. indica

$\mathrm{T}_{6} \mathrm{SR}+3 \% \mathrm{DLB}$ of $A$. indica

Chickpea variety CMS-2118-2508 was obtained from National Agriculture Research Centre (NARC) Islamabad, Pakistan. Seeds were surface sterilized for 3 min in $1 \%$ sodium hypochlorite solution, followed by consecutive washings in autoclaved distilled water. Eight seeds were sown in each plastic pot and irrigated on regular basis. The pots were monitored regularly for the development of collar rot symptoms, which were

Table 1 List of oligonucleotide primers used for the characterization of Sclerotium rolfsii at molecular level

\begin{tabular}{llll}
\hline No. & Primer name & $5^{\prime}$ to 3' sequence & Annealing temperature \\
\hline $\mathbf{1}$ & ITS 1 forward & TCCGTAGGTGAACCTGCGG & $60^{\circ} \mathrm{C}$ \\
$\mathbf{3}$ & ITS 4 reverse & TCCTCCGCTTATTGATATGC & $62^{\circ} \mathrm{C}$ \\
$\mathbf{4}$ & B-tubulin forward & GGTAACCAAATCGGTGCTGCTTC & \\
\hline
\end{tabular}




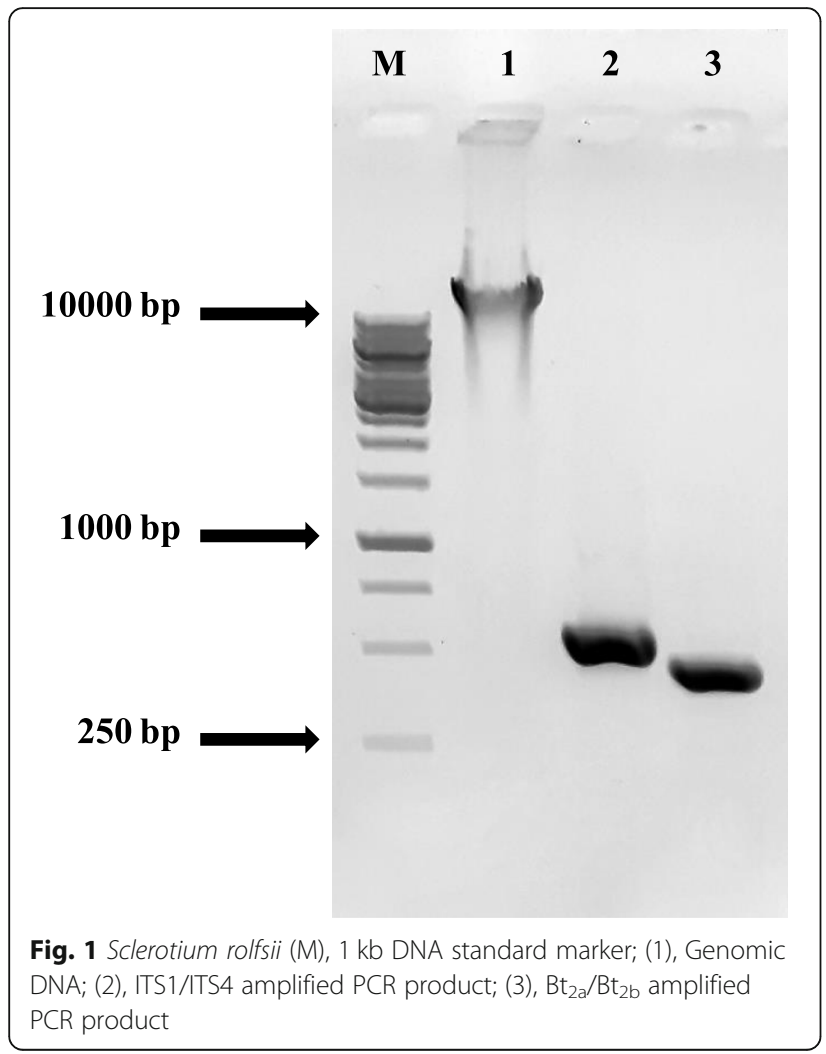

confirmed later on 30th day after the seed sowing. Then the plants were uprooted to measure shoot and root lengths and fresh and dry weights. Data regarding plant mortality were recorded carefully after 15 and 30 days of seed sowing by applying the following formula:

$$
\text { Mortality }(\%)=\frac{\text { No.of plants died due to disease }}{\text { Total No.of plants }} \times 100
$$

\section{Statistical analysis}

All the data were analyzed by ANOVA, followed by Tukey HSD test $(P \leq 0.05)$, using computer software Statistix 8.1.

\section{Results and discussion}

Identification based on rDNA sequence analysis

Nucleotide sequence analyses of ITS and beta tubulin regions of rDNA were carried out to characterize the $S$. rolfsii genetically. PCR amplified products of ITS and beta tubulin rDNA yielded approximately 527 and 448 bp amplicon sizes, respectively, when visualized at $1 \%$ agarose gel (Fig. 1). Nucleotide sequences of ITS and beta tubulin amplified rDNA were deposited in GenBank under the accession No. MT573510 and MN736404, respectively.

\section{In vitro antifungal bioassays}

In vitro effect of methanolic leaf extract against the growth of $S$. rolfsii was illustrated in Fig. 2. It clearly

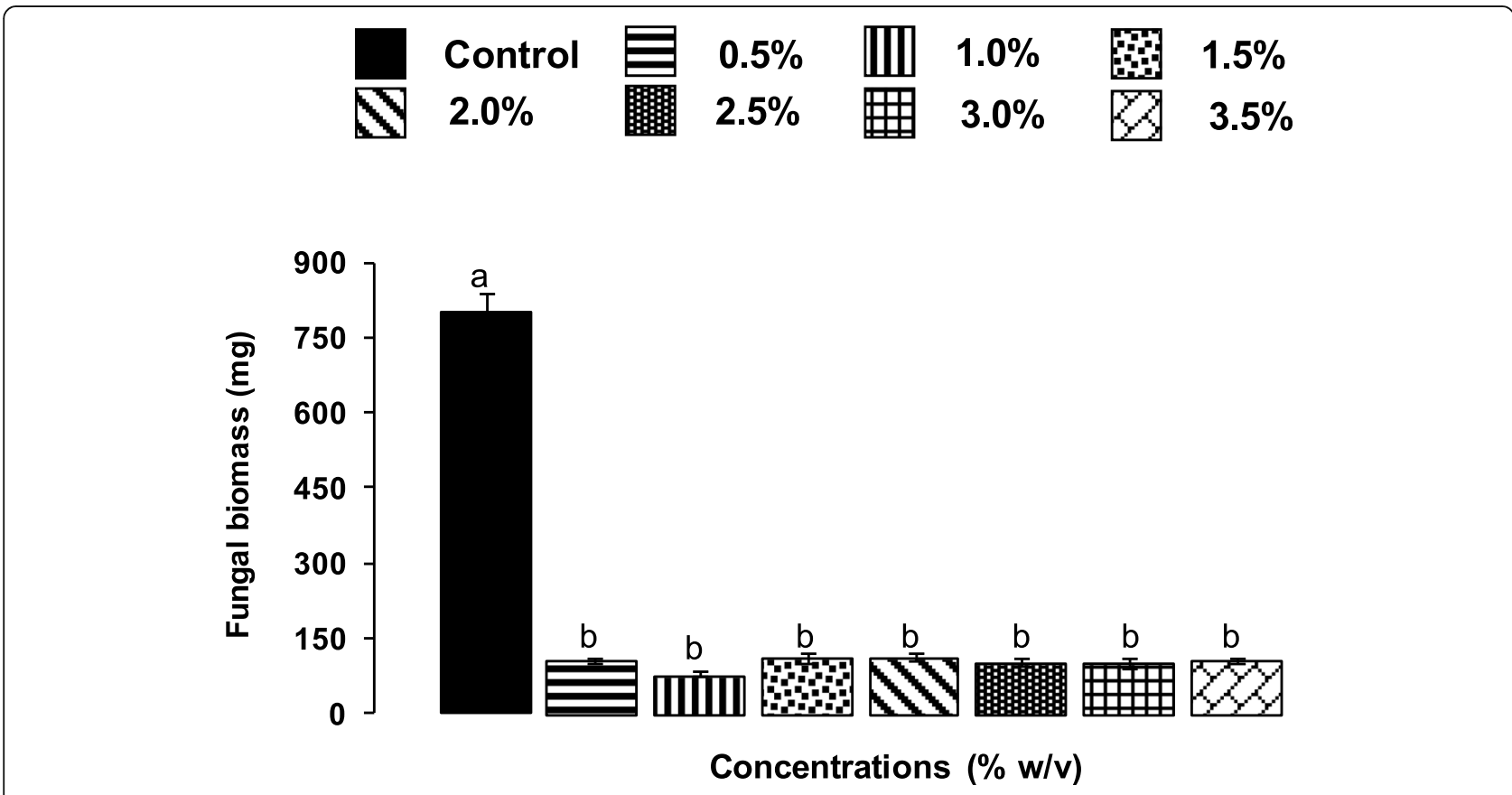

Fig. 2 Effect of different concentrations of methanol leaf extract of Azadirachta indica on biomass of Sclerotium rolfsii. Vertical bars show standard errors of means of five replicates. Values with different letters at their top show significant difference $(P \leq 0.05)$ as determined by Tukey HSD test 
indicated that all the concentrations significantly $(P \leq$ $0.05)$ reduced the fungal biomass than the control. Different concentrations were found to reduce the fungal biomass by $86-90 \%$ over control treatment. These findings are in the favor of work of Obongoya et al. (2010) who evaluated the antifungal efficacy of Neem extract against Fusarium oxysporum with promising results. Generally, plant extract efficacy was influenced by the level of concentrations used in experimental work; however, in the present study, the increase in concentration did not result in a parallel decline in mycelial growth of the pathogen. Likewise, Akaeze and AduramigbaModupe (2017) checked in vitro efficacy of Neem plant extracts against $F$. oxysporum, where all the concentrations of methanolic extract were found almost equally effective against $F$. oxysporum.

\section{Pot trial}

After 15 days of sowing, the highest seedling mortality (42\%) was recorded in positive control, which increased to $56 \%$ after 30 days of sowing. Mancozeb application was highly effective in reducing plant mortality. In this fungicidal treatment, the plant mortality was just 3\% after 15 days of sowing that was increased to $28 \%$ after 30 days of sowing. The lowest concentration (1\%) of dry leaf biomass (DLB) did not show any remarkable effect as there were 33 and $49 \%$ disease incidences after 15 and 30 days of sowing, respectively. However, 2 and 3\% DLB significantly reduced disease incidences over positive control both after 15 and 30 days of sowing (Fig. 3).

In pot trials, the collar rot of chickpea was managed through the use of a fungicide namely, mancozeb and Neem dry leaf biomass. Disease highly occurred in positive control, whereas negative control was disease free. The disease incidence was reduced significantly in Neem dry leaf biomass and mancozeb-treated soils. The fungicide gave better results than the dry leaf biomass. There are reports that fungicides are highly effective for the control of target fungus S. rolfsii (Shirsole et al. 2019). Mancozeb proved to be a broad-spectrum fungicide effective against downy mildew, collar rot, foot rot, damping-off, stem rot, root rot, southern blight, bulb rot, and wilt diseases caused by Lagenaria siceraria, Alternaria solani, Rhizoctonia solani, Sclerotium rolfsii,

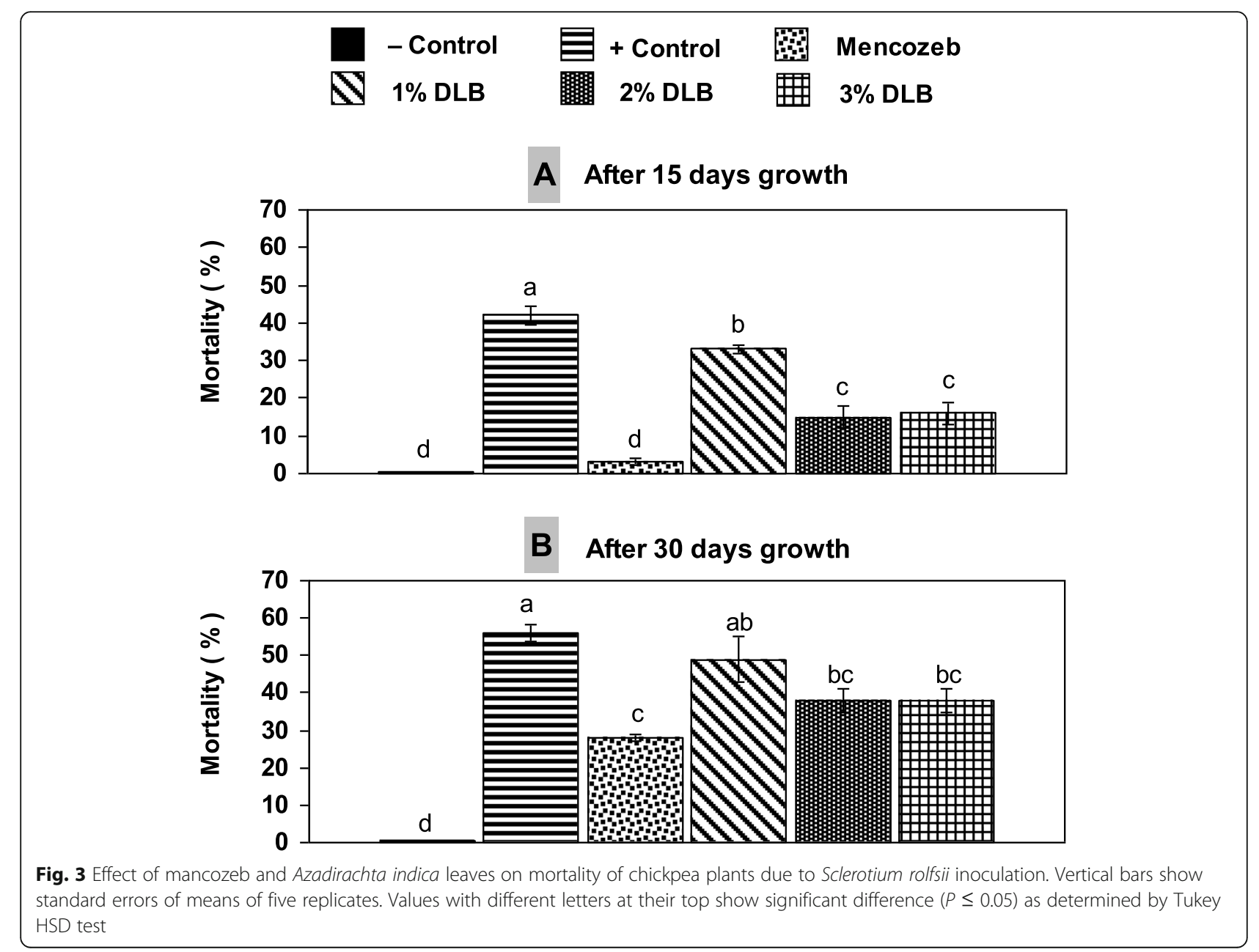


R. bataticola, and F. oxysporum (Majumder et al. 2016; Gowari et al. 2017; Bagri et al. 2019; Michel-Aceves et al. 2019 and Vani et al. 2019). Rather et al. (2012) concluded that many fungicides like tebuconazole, penconazole, vitavax, hexaconazole, thiophanate methyl, and mancozeb were effective against $S$. rolfsii. Similarly, Madhavi and Bhattiprolu (2011) reported that in field experiments, mancozeb was highly effective for the control of $S$. rolfsii responsible of dry root rot in chilies. In a previous study, it was also reported that $F$. oxysporum isolated from the cucumber-infected seeds was completely inhibited even at lower concentrations of mancozeb (Sultana and Ghaffar 2013).

All the concentrations of Neem dry leaf biomass significantly reduced the pathogen growth and disease incidence over control. In a previous study, Obongoya et al.

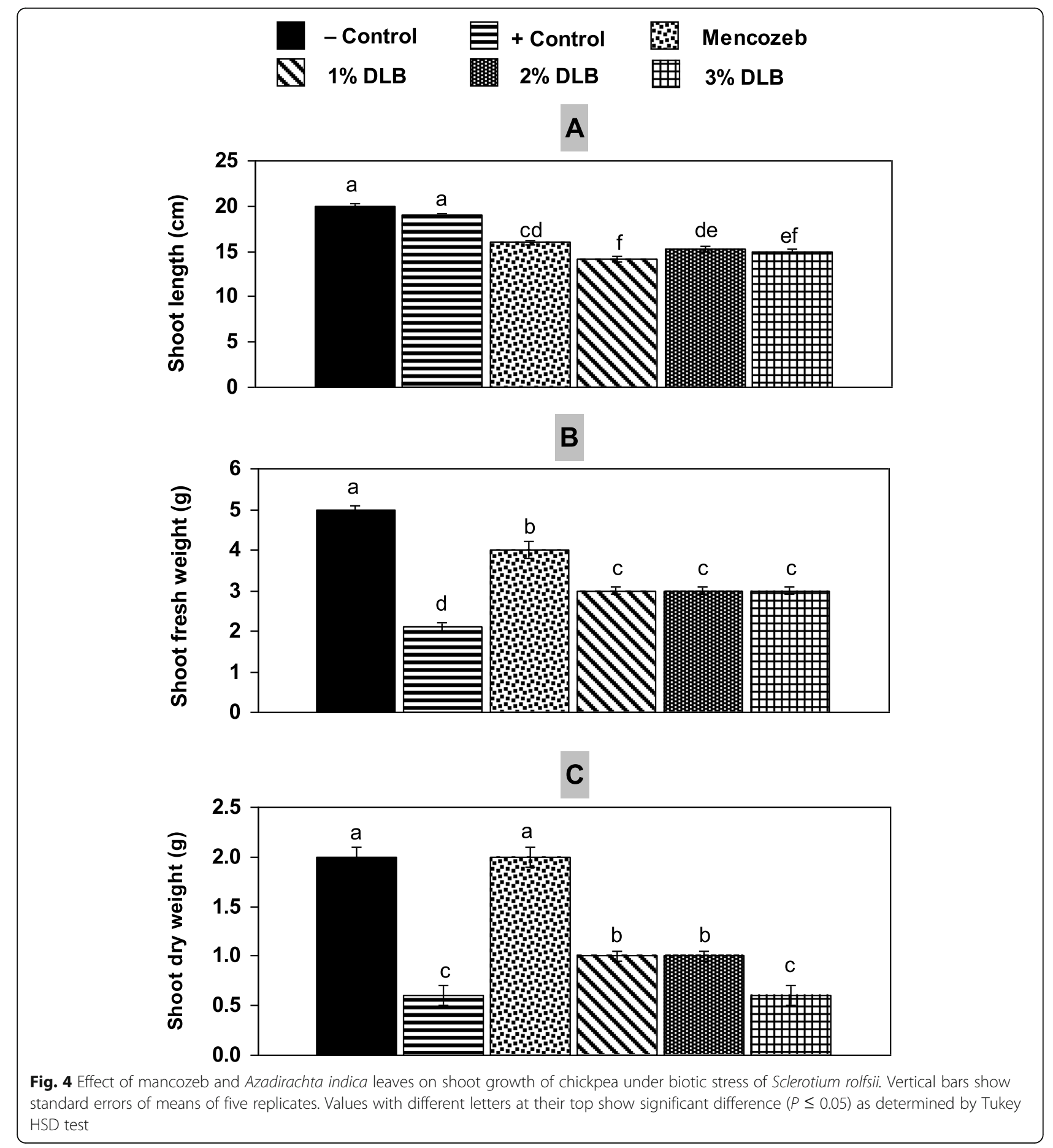


(2010) revealed that $F$. oxysporum, the pathogen of yellow disease, can effectively be managed through the botanicals isolated from Neem plant. In their study, soil amendment with Neem was also observed to be effective in enhancing the plant size and seed germination with minimum seedling mortality by $F$. oxysporum. Ezeonu et al. (2018) also gave similar report regarding the effectiveness of Neem seed, bark, and leaf ethanolic extracts against fungal pathogens namely, Aspergillus oryzae, A. niger, Rhizopus stolonifer, A. ochraceus, and Lasiodiplodia theobromae responsible for rot diseases in cocoyam and yam plants. Obtained results agree with the findings of Ali et al. (2017b) who discovered that nano emulsions of Neem represent excellent antifungal activity against many phytopathogenic fungi such as follows: S. rolfsii and Rhizoctonia solani that cause collar rot, dampingoff, wilting, and dry root rot under field conditions.

The effect of $A$. indica DLB and fungicide on the shoot growth of chickpea is shown in Fig. 4. There was insignificant difference in shoot length between positive and negative control treatments. Applications of 1, 2, and 3\% DLB of $A$. indica and mancozeb significantly reduced shoot length over negative and positive controls. In contrast, shoot fresh weight at 1 and 2\% DLB amended treatments showed significant increases over positive control, whereas in mancozeb treatment, it was significantly lower than negative control. Shoot dry biomass in $1 \%$ amendment was at par with negative control. However, as the concentration of DLB was increased, it adversely affected the production of shoot biomass.

The effect of DLB and fungicide on the root growth is shown in Fig. 5. Significant reductions in positive and negative control root lengths with enhanced dry root weights were recorded in comparison to mancozeb application. The root lengths and dry biomasses increased significantly in 1, 2, and 3\% concentrations of DLB over positive control. The effect of $1 \%$ DLB was more pronounced than the effect of higher concentrations of 2 and $3 \%$. In general, increase in DLB dose resulted in reduction of root growth parameters.
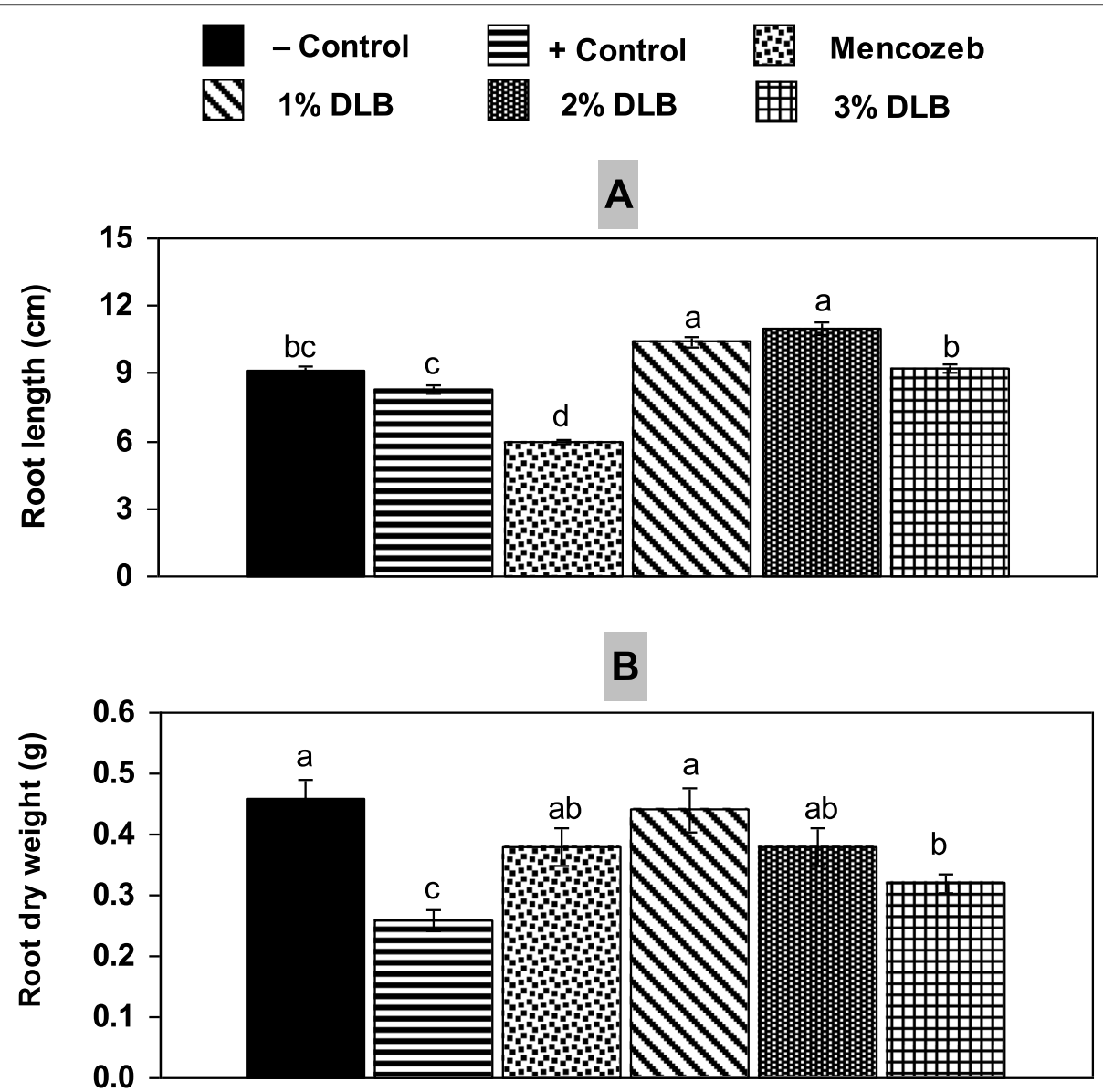

Fig. 5 Effect of mancozeb and Azadirachta indica leaves on root growth of chickpea under biotic stress of Sclerotium rolfsii. Vertical bars show standard errors of means of five replicates. Values with different letters at their top show significant difference $(P \leq 0.05)$ as determined by Tukey HSD test 


\section{Conclusion}

The present findings clearly indicated that Neem leaf extract and soil amendment with leaf dry biomass were highly effective in controlling in vitro and in vivo growth of $S$. rolfsii.

\section{Abbreviations}

ITS: Internal transcribed spacer; MEA: Malt extract agar; CTAB: Cetyl trimethyl ammonium bromide; PCR: Polymerase chain reaction; ANOVA: Analysis of variance; DLB: Dry leaf biomass

\section{Acknowledgements}

Not applicable

\section{Authors' contributions}

Miss Iqra Haider Khan conducted the study and wrote a part of the manuscript. Arshad Javaid supervised the work, analyzed the data, and approved the final manuscript. Azher Hameed Al-Taie contributed in paper writing. Dildar Ahmed did GC_MS analysis. The authors read and approved the final manuscript.

\section{Funding}

Not applicable

\section{Availability of data and materials}

The datasets used and/or analyzed during the current study are available from the corresponding author on reasonable request.

\section{Ethics approval and consent to participate}

Not applicable

\section{Consent for publication}

All authors are agreed to publish this paper.

\section{Competing interests}

The authors declare that they have no competing interests.

\section{Author details}

${ }^{1}$ Institute of Agricultural Sciences, University of the Punjab, Lahore, Pakistan.

${ }^{2}$ College of Agriculture, University of Wasit, Kut, Iraq. ${ }^{3}$ Department of

Chemistry, Forman Christian College, Lahore, Pakistan.

Received: 18 May 2020 Accepted: 15 July 2020

Published online: 21 July 2020

\section{References}

Akaeze OO, Aduramigba-Modupe AO (2017) Fusarium wilt disease of tomato: screening for resistance and in-vitro evaluation of botanicals for control; the Nigeria case. J Microbiol Biotechnol Food Sci 7:32-36

Ali A, Javaid A, Shoaib A (2017a) GC-MS analysis and antifungal activity of methanolic root extract of Chenopodium album against Sclerotium rolfsii. Planta Daninha. 35: Article No. e017164713. DOl: https://doi.org/10.1590/ S0100-83582017350100046.

Ali EOM, Shakil NA, Rana VS, Sarkar DJ, Majumder S, Kaushik P, Singh BB, Kumar J (2017b) Antifungal activity of nano emulsions of neem and citronella oils against phytopathogenic fungi, Rhizoctonia solani and Sclerotium rolfsii. Ind Crop Prod 108:379-387

Bagri RK, Singh J, Goyal SK, Chawla N, Kumari M (2019) Integrated disease management of downy mildew in bottle gourd (Lagenaria siceraria (Mol.) Stand). J Entomol Zool Stud 7:315-317

Bajwa AA, Zulfiqar U, Sadia S, Bhowmik P, Chauhan BS (2019) A global perspective on the biology, impact and management of Chenopodium album and Chenopodium murale: two troublesome agricultural and environmental weeds. Environ Sci Pollut Res 26:5357-5371

Bundschuh M, Elsaesser D, Stang C, Schulz R (2016) Mitigation of fungicide pollution in detention ponds and vegetated ditches within a vine-growing area in Germany. Ecol Eng 89:121-130

Doyle JJ, Doyle JL (1990) Isolation of plant DNA from fresh tissue. Focus 12:39-40
Ezeonu CS, Imo C, Agwaranze DI, Iruka A, Joseph A (2018) Antifungal effect of aqueous and ethanolic extracts of neem leaves, stem, bark and seeds on fungal rot diseases of yam and cocoyam. Chem Biol Technol Agric 5:1-9

Farr D, Rossman A, Palm M, Cray E (2007) Fungal databases. Systematic Botany \& Mycology Laboratory, ARS, USDA. Retrieved from http://nt.ars-grin.gov/ fungaldatabases.

Gowari JL, Dhutraj DN, Kadam VA, Pawar DV (2017) Integrated management of foot rot of betelvine caused by Sclerotium rolfsii. J Plant Dis Sci 12:125-128

Hadi S, Hameed S, Ali S, Al-Karkhi IHT (2019) Evaluation Eruca Sativa aqueous and alcoholic extract on Fusarium oxysporum growth. Ind J Public Health Res Dev 10:1933-1938

Ilyas MB, Chaudhry MA, Javed N, Ghazanfar MU, Khan MA (2007) Sources of resistance in chickpea germplasm against Ascochyta blight. Pak J Bot 39: 1843-1847

Javaid A, Afzal L, Shoaib A (2017a) Biological control of charcoal rot of mungbean by Trichoderma harzianum and shoot dry biomass of Sisymbrium irio. Planta Daninha 35:e017165756

Javaid A, Afzal R, Shoaib A (2020) Biological management of southern blight of chili by Penicillium oxalicum and leaves of Eucalyptus citriodora. Int J Agric Biol 23:93-102

Javaid A, Khan IH (2016) Management of collar rot disease of chickpea by extracts and soil amendment with dry leaf biomass of Melia azedarach L. Phil Agric Sci 99:150-155

Javaid A, Niaz L, Shoaib A (2017b) Effect of incorporation of leaf biomass of Coronopus didymus on management of basal rot disease of onion and plant physiology. Int J Agric Biol 19:445-452

Javaid A, Qudsia H, Shoaib A (2017c) Bioassays guided fractionation of Senna occidentalis for identification of natural antifungal constituents against Macrophomina phaseolina. Planta Daninha 35:e017163483

Javaid A, Saddique A (2011) Management of Macrophomina root rot of mungbean using dry leaves manure of Datura metel as soil amendment. Span J Agric Res 9:901-905

Kokub D, Azam F, Hassan A, Ansar M, Asad MJ, Khanum A (2007) Comparative growth, morphological and molecular characterization of indigenous $\mathrm{S}$. rolfsii strains isolated from different locations of Pakistan. Pak J Bot 39:1849-1866

Madhavi GB, Bhattiprolu SL (2011) Integrated disease management of dry root rot of chilli incited by Sclerotium rolfsii (Sacc.). Int J Plant Ani Environ Sci 1:31-37

Majumder S, Shakil NA, Kumar J, Banerjee T, Sinha P, Singh BB, Garg P (2016) Ecofriendly PEG-based controlled release nano-formulations of Mancozeb: synthesis and bioefficacy evaluation against phytopathogenic fungi Alternaria solani and Sclerotium rolfsii. J Environ Sci Health 51:873-880

Maurya S, Rashmi S, Singh DP, Singh HB, Srivastava JS, Singh UP (2007) Phenolic compounds of Sorghum vulgare in response to Sclerotium rolfsii infection. J Plant Interact 2.25-29

Michel-Aceves AC, Diaz-Najera JF, Ariza-Flores R, Otero-Sanchez MA, EscobarMartinez R, Avendano-Arrazate CH (2019) Control alternatives for dampingoff in tomato seedling production. Int J Exp Bot 88:325-333

Naqvi SF, Javaid A, Qureshi MZ (2019) Evaluation of antifungal potential of leaf extract of Chenopodium murale against Fusarium oxysporum f. sp. lycopersici. Planta Daninha 37: e019199050

Obongoya BO, Wagai SO, Odhiambo G (2010) Phytotoxic effect of selected crude plant extracts on soil borne fungi of common bean. Afr Crop Sci J 18:15-20

Pakistan Economic Survey (2017-18) Chapter 2: agriculture. Ministry of Finance, Government of Pakistan.

Rather TR, Razdan VK, Tewari AK, Shanaz E, Bhat ZA, Hassan MG, Wani TA (2012) Integrated management of wilt complex disease in bell pepper (Capsicum annum L.). J Agric Sci 4:141-147

Remesal E, Landa BB, Jimenez MD, Navas JA (2013) Sequence variation in two protein-coding genes correlates with mycelial compatibility groupings in Sclerotium rolfsii. Pak J Phytopathol 103:479-487

Shirsole SS, Khare N, Lakpale N, Kotasthane AS (2019) Evaluation of fungicides against Sclerotium rolfsii Sacc. incitant of collar rot of chickpea. Pharma Innov J 8:310-316

Sultana N, Ghaffar A (2013) Effect of fungicides, microbial antagonists and oil cakes in the control of Fusarium oxysporum, the cause of seed rot and root infection of bottle gourd and cucumber. Pak J Bot 45:2149-2156

Tarafdar A, Rani TS, Chandran USS, Chobe DR, Sharma M (2018) Exploring combined effect of abiotic (soil moisture) and biotic (Sclerotium rolfsii Sacc.) stress on collar rot development in chickpea. Front Plant Sci 9: Article Number 1154 
Vani MS, Kumar S, Gulya R (2019) In vitro evaluation of fungicides and plant extracts against Fusarium oxysporum causing wilt of mungbean. Pharma Innov 8:297-302

Varol IS, Kardes YM, Irik HA, Kirnak H, Kaplan M (2020) Supplementary irrigations at different physiological growth stages of chickpea (Cicer arietinum L.) change grain nutritional composition. Food Chem 303:Article Number 125402

Weber RWS, Raddatz C, Kutz S (2018) Relative abundance and fungicide resistance patterns of Botrytis cinerea and B. pseudocinerea on apple in Northern Germany. J Plant Dis Prot. 125:501-4.

\section{Publisher's Note}

Springer Nature remains neutral with regard to jurisdictional claims in published maps and institutional affiliations.

\section{Submit your manuscript to a SpringerOpen ${ }^{\mathcal{O}}$ journal and benefit from:}

- Convenient online submission

- Rigorous peer review

- Open access: articles freely available online

- High visibility within the field

- Retaining the copyright to your article

Submit your next manuscript at $\boldsymbol{\nabla}$ springeropen.com 